\title{
Factors which Influence Keeping within a Project Budget in IT Projects
}

\author{
Barbara Gladysz, Dorota Kuchta, \\ Kazimierz Frączkowski, Andrzej Pawlicki*
}

\begin{abstract}
The purpose of the paper is to analyse which factors influence keeping within a project budget in IT projects. A sample of IT projects was examined by means of a questionnaire, where IT project managers were asked to what extent they kept within the budget in their projects, as well as about various features of the projects, the project management processes used and the organisation where the projects were run. A statistical analysis was performed which indicated which factors have a substantial influence on the risk of exceeding the project budget. A real-world IT project was analysed from the point of view of the relation between the planned and the actual budget as well as of the occurrence of the factors identified in the statistical analysis. The value of the paper consists in the fact that it shows to IT project managers, on the basis of a quantitative analysis, how to influence positively the probability of keeping within a project budget.
\end{abstract}

Keywords: IT project; project budget; project success

\section{Introduction}

A very high number of IT projects (46-54\% between 2002 and 2012, (Standish Group 2013), exceeded their budget. The consequences of this may be serious. A substantial difference between projects' actual and planned budgets may lead to serious financial problems for organisations, as well as the loss of important opportunities.

Keeping within a project budget is considered to be one of the principal project success determinants. Project success is defined in many ways for projects in general (Belassi, Tukel 1996; Shao et al. 2012; Tukel, Rom 2001; Mir, Pinnington 2014; Westerveld 2003; Camilieri 2011), and for software projects (Wateridge 1998; Fan 2010; Jørgensen 2014), but in all approaches the budget aspect is important. Of course, there are situations where accomplishing a project within the budget limit is not the most important aspect, but it is usually of fairly high or very high importance.

\footnotetext{
* dr hab. inż. Barbara Gładysz, Politechnika Wrocławska, Wydział Informatyki i Zarządzania, ul. Smoluchowskiego 25, 50-372 Wrocław, e-mail: barbara.gladysz@pwr.edu.pl; dr hab. inż., prof. PWr Dorota Kuchta, Politechnika Wrocławska, Wydział Informatyki i Zarządzania, ul. Smoluchowskiego 25, 50-372 Wrocław e-mail: dorota. kuchta@pwr.edu.pl; dr inż. Kazimierz Frączkowski, Politechnika Wrocławska, Wydział Informatyki i Zarządzania, ul. Smoluchowskiego 25, 50-372 Wrocław, e-mail: kazimierz.fraczkowski@pwr.edu.pl; mgr Andrzej Pawlicki, Politechnika Wrocławska, Wydział Informatyki i Zarządzania, ul. Smoluchowskiego 25, 50-372 Wrocław, e-mail: andrzej.pawlicki@pwr.edu.pl.
} 
Also, it has to be considered that IT projects are often very expensive and that many of them are funded from public money (among other UE funds). Thus, if budget limits are seriously violated, then huge amounts of public money may be lost, which becomes an important problem for societies. It is thus important to find out which factors are most responsible for budget problems.

In the literature, there have been extensive studies of project success factors, including the success in terms of budget for projects in general (Belassi, Tukel 1996; Camilieri 2011; Fortune, White 2006). They usually, with very few exceptions (e.g. Flyvbjerg et al. 2004) treat project success in a complex way, considering the budget keeping criterion as one of several criteria. Also, there are studies on projects from a selected field (e.g. Chan, Chan 2004; Barbolla, Corredera 2009), also on IT projects (Chow, Cao 2008; Stankovic et al. 2013; Jørgensen 2014; Ramos, Mota 2014, Drury-Grogan 2014; Montequin et al. 2014).

However, the studies of IT project success factors usually also treat project success in a complex way and do not explore explicitly the problem of keeping within the budget. There are only two exceptions to this rule: in Jørgensen, Halkjelsvik and Kitchenham (2012), the budget problem of IT projects was explored explicitly, but only with respect to one potential success factor - the project size. The conclusion is that no statistically-binding result with regard to the link between project cost problems and project size can be formulated. In (Chow, Cao 2008) various aspects of IT project success (cost, time and quality) are treated individually and the statistical analysis performed showed that project cost is influenced significantly only by factors related to people. However, this study concerns, exclusively, projects led according to an agile methodology. In conclusion, it has to be said that it is still unknown which factors are important to keeping within the budget of IT projects.

The goal of the paper is thus to present the results of an attempt to determine those factors. More specifically, the goal was to determine the factors which influence in a significant way: variable $Y=\left(b_{a}-b_{p}\right) / b_{p}$, where bp is the planned budget and ba the actual one. In the research questionnaires, statistical analysis and case study methods were used.

The outline of the paper is as follows: in Section 2 the research methodology is described; in Section 3 the results of the statistical analysis are presented; in Section 4 a description of a real-world IT project is presented and analysed against the background of the results presented in Section 3; and the final part of the paper presents some conclusions.

\section{Research Description}

The research made use of questionnaires filled in by project managers from 80 IT projects based in Poland (more questionnaires were received, but some of them were incomplete or unacceptable for some other reason). The planned duration of the examined projects was 1-60 months, and the planned budget 9,500-8,000,000 Polish zlotys. The project teams were composed of 2-80 members. 
On the basis of the literature listed in the introduction, a list of potential success factors was identified. This list, together with the options from which the questionnaire respondents were requested to select one, were as follows:

1) Project type (development of a new system, development of an existing system, implementation of an IT solution);

2) the fact of using a specific project management methodology (one of the formal methodologies, an agile methodology, no methodology);

3) the fact of evaluating the project risk before the project start (yes, no);

4) a systematic project risk evaluation during project realisation (yes, no);

5) the participation of the project team in project risk management (yes, no);

6) the existence of project risk management procedures in the organisation (yes, no);

7) the fact that the project manager has one of the acknowledged project management certificates (yes, no);

8) the size of the customer organisation, classified on the basis of the number of employees: micro (1-9), small (10-49), middle (50-249), large (250-1,999,) very large (more than 2,000);

9) the number of experts in the project team (actual number; experts both in project management and in the field are included);

10) the number of customer representatives working together with the project team (actual number);

11) the fact of using a specific project risk management methodology (yes, no);

12) the fact of using a risk register (yes, no);

13) the fact of preparing a risk management plan (yes, no);

14) the fact of using a systematic business justification for the project (yes, no);

15) the fact of using any other document for project risk management (yes, no);

16) the number of project risk management documents used (the actual number);

17) the fact of re-estimating the project risk at each change in the project (yes, no);

18) the fact of re-estimating the project risk in project control points (yes, no);

19) the fact that the sponsor participated in project risk management (yes, no);

20) the number of projects which were operating simultaneously in the organisation (actual number);

21) the experience of the project manager (evaluated by the respondent as a number $0-100)$;

22) the experience of the project manager in the field of the project (evaluated by the respondent as a number $0-100$ );

23) the weight attached by the project manager to project risk management (decisively none, rather small, rather high, decisively high);

24) the fact that the project manager has done some training in project risk management (yes, no); 
25) the fact that the project manager has done some training in soft project management (yes, no);

26) the fact that project risk management on the project level was supported by project risk management procedures at the organisational level (yes, no);

27 ) the size of the organisation realising the project (see 10);

28) the frequency with which the customer reviewed and accepted the project progress (less often than once every three months, once every three months, once every two months, once a month, more often than once a month);

29) the degree to which the scope of the project was outsourced (less than $10 \%$ of the scope, $10-25 \%, 25-50 \%$, more than $50 \%$ );

30) risk severity in various project management aspects (e.g. project planning and control), evaluated by the respondents (using the scale 1-4; the higher the value, the higher the severity).

The list was the basis for constructing the independent variables. As for the dependent variable, the respondents were requested to give the values of the actual and planned budget of their projects.

Further on in the research, a variance analysis (for qualitative factors) and a correlation analysis (for measurable factors) was used. The computations were carried out by means of the SPSS application.

\section{Factors influencing keeping within the project budget}

In the examined population, in $51.2 \%$ of projects the budget was kept (in several projects the actual budget was even smaller than the planned one); in the remainder (49.8\%) it was exceeded. The mean percentage difference between the actual budget $\left(b_{a}\right)$ and the real budget $\left(b_{p}\right)$ in relation to the planned budget $Y=\left(b_{a}-b_{p}\right) / b_{p}$ was equal to $10.3 \%$. The dispersion of variable was $31 \%$. The research showed that variable is influenced in a significant way by the following factors:

- the customer organisation size,

- whether in the organisation of realising the project other projects are run simultaneously,

- the frequency of accepting changes in the project scope by the customer,

- factors linked to project risk management (applying risk identification or not; the way it is executed; using project business justification or not; preparing a project risk management plan or not; and the number of project risk management documents used).

In Tables 1-6 the influence of individual factors on the expected value of is presented.

In Table 1, it can be seen that the larger the customer organisation, the closer the actual budget is to the planned. 


\section{Table 1}

Mean percentage deviation of the actual budget from planned based on customer organisation size

\begin{tabular}{llrrl}
\hline \multirow{2}{*}{ Customer organisation size } & \multirow{2}{*}{$\begin{array}{l}\text { No. of pro- } \\
\text { jects }\end{array}$} & \multicolumn{3}{l}{ Subset for alpha $=0.05$} \\
\cline { 3 - 5 } & 33 & -0.0203 & 2 & 3 \\
\hline Very large & 33 & 0.0815 & 0.0815 & \\
Large & 19 & 0.1023 & 0.1023 & \\
Middle & 13 & & 0.3728 & 0.3728 \\
Micro & 9 & & & 0.4465 \\
Small & 6 & & & \\
\hline
\end{tabular}

Source: authors' own calculations.

In Table 2, it is shown that in organisations running several projects at the same time, the mean value of variable is $7.5 \%$, while in organisations running single projects; this value is much larger - equal to $35 \%$.

\section{Table 2}

Mean percentage deviation of actual budget from planned based on whether several projects are run in the organisation at the same time (significance level $=0.05$ )

\begin{tabular}{lll}
\hline $\begin{array}{l}\text { Are other projects run simultaneously in the organisation } \\
\text { which is running the project in question? }\end{array}$ & No. of projects & Mean \\
\hline No & 10 & 0.3403 \\
Yes & 66 & 0.0749 \\
\hline
\end{tabular}

Source: authors' own calculations.

\section{Table 3}

Mean percentage deviation of the actual budget from being planned and based on the frequency of accepting the project progress by the customer

\begin{tabular}{lccc}
\hline Frequency of accepting project progress & No. of projects & \multicolumn{2}{c}{ Subset for alpha $=0.05$} \\
\cline { 3 - 4 } by the customer & 21 & 1 & 2 \\
\hline Once a month & 11 & -0.0388 \\
Once every two months & 8 & 0.0065 & 0.0291 \\
More often than once a month & 27 & 0.0897 & 0.3972 \\
Less often than once every three months & 4 & & \\
Every three months &
\end{tabular}

Source: authors' own calculations.

Another important factor which influences the relation between planned and actual budgets is the nature of cooperation with the customer, as illustrated in Table 3 . The highest value of (39.7\%) occurs in projects where the customer accepts the project progress once every three months. In projects where the project progress was accepted more frequently or 
only sporadically (less often than every three months) the actual budget was equal to being planned with the precision of $9 \%$.

Another group of factors influencing keeping the project within the budget regarding factors linked to project risk management.

Table 4 shows that in projects where no risk identification is conducted, the mean value of is $25.2 \%$, while in projects where risk identification is used, this value is equal to $9.8 \%$. In the same table we can see that in projects where expert knowledge is used for risk identification, the mean value of is $2.2 \%$, while in the rest of the projects it is equal to $6.8 \%$.

\section{Table 4}

Mean percentage deviation of an actual project budget planned and based on whether risk

identification is conducted and whether it is based on expert knowledge (significance level $=0.05$ )

\begin{tabular}{lllll}
\hline \multirow{2}{*}{ Document } & \multicolumn{2}{l}{ No risk identification } & \multicolumn{2}{l}{ Expert knowledge is the basis for risk identification } \\
\cline { 2 - 5 } & no. of projects & mean & no. of projects & mean \\
\hline No & 49 & 0.0977 & 51 & 0.1680 \\
Yes & 19 & 0.2524 & 19 & 0.0225 \\
\hline
\end{tabular}

Source: authors' own calculations.

In Table 5 it can be seen that if project business justification is systematically evaluated, helping to manage the risk of continuing a project which is no longer justified, and if a project management plan is worked out, then the value of is respectively $3.5 \%$ and $0.8 \%$, and without those documents is much higher.

\section{Table 5}

Mean percentage deviation of the actual budget with respect to being planned and based on whether project business justification and a project risk management plan are used ( significance level $=0.05$ )

\begin{tabular}{lllll}
\hline \multirow{2}{*}{ Document } & \multicolumn{2}{l}{ Project business justification } & \multicolumn{2}{l}{ Project risk management plan } \\
\cline { 2 - 5 } & no. of projects & mean & no. of projects & mean \\
\hline No & 45 & 0.1558 & 55 & 0.1464 \\
Yes & 35 & 0.0352 & 25 & 0.0077 \\
\hline
\end{tabular}

Source: authors' own calculations.

Table 6 shows that in projects where no project risk management documents are used, variable is equal to $31.7 \%$, and if there are some project risk management documents, even only one or two, it is much lower.

The results can be summarised as follows. Large organisations carrying out IT projects seem to have more experience in project management, or possibly attach more importance to project cost management because their projects are more likely to be completed within a budget, compared to projects in smaller IT organisations. Also, if an organisation runs 
several projects at the same time, its projects are more likely to be within a budget compared to those organisations where projects are conducted one at a time. Here the reasons may be the same: they may include experience and more respect for project cost management.

\section{Table 6}

Mean percentage deviation of actual budget with respect to being planned and based on the number of project risk management documents used

\begin{tabular}{llll}
\hline No. of project risk management & \multirow{2}{*}{ No. of projects } & \multicolumn{2}{c}{ Subset for alpha $=0.1$} \\
\cline { 2 - 4 } documents used & 11 & -0.1045 & 2 \\
\hline More than 2 & 20 & 0.0628 & \\
2 & 34 & 0.0793 & 0.3173 \\
1 & 14 & & 0.06 \\
0 &
\end{tabular}

Source: authors' own calculations.

A very important factor in any organisation is cooperation with the customer. If the customer is involved in following project progress more frequently (more than once every three months), it is more likely the project will be within the budget.

Another very important factor helping to stay within the project planned budget is project risk management. If an IT organisation wants to complete its projects within the budget, it should apply documented project risk management; it should use project risk identification based on expert knowledge, use project business justification and put together a project risk management plan.

In the following section a real-world project is described and analysed, taking into account these results. The aim of the case study was to see how the results given by the statistical analysis could be used in practice and expanded on in future research.

\section{Case study}

The description below is based on the testimony of the project manager from a company to be called 'the Contractor'. Firstly, the project will be presented along with its goal, the organisation it was executed by, the customer, the tasks to be accomplished and the problems encountered. It is known that the project was run in a large organisation with several projects being run at the same time, and the project budget was seriously exceeded. Therefore in this case two of the factors identified above - the organisation size and the number of projects run at the same time - did not prove to help in keeping within the budget, although they could have, as was shown by the statistical analysis. However, the question can still be asked whether the other factors applicable to all organisations, as displayed here, had an influence shown by the statistical results. 


\section{Description of the Project and the Project Goal}

Currently, many companies decide to reduce their operational costs and make the move to outsource their IT resources and services. In this case, an external service provider takes the responsibility for business-critical systems and controls the IT infrastructure. The project in question was based on such a scenario. A prosperous enterprise decided to choose the company executing the project as their outsourcing partner. The company executing the project will be called 'Contractor' from this point on.

The goal of the project was to migrate approximately 300 virtual and physical servers from the Customer's data centre to the Contractor's data centre. All parameters, data, components, operating systems and applications installed on the Customer's servers needed to remain unchanged after the migration. The Customer and the Contractor had to work together to make this migration successful. All had to be completed within nine months.

The Customer's company was operating in the private sector. Members of the project team were located in a country in Western Europe. All team members were located in one place, so they could communicate with each other directly.

The Contractor mainly dealt with IT services outsourcing. It was a large company hiring many thousands of people all over the world. Members of the project team came from various countries across different continents: Europe, Asia, Africa and South America. Having project team members working in different time zones enabled running the migration continuously 24 hours a day (including weekends). The purpose of that was in order to shorten the project duration.

The project team was divided between the two organisations.

From the Customer's side:

1. Project Sponsor(s) - members of the management board ('business part').

2. IT Director - responsible for managing IT managers (additionally held the role of a facilitator of communication between the IT department and the customer's 'business part').

3. IT Managers (2) - responsible for managing IT teams.

4. IT teams (approximately 15) - Operating System Administrators, System Architects, Database Administrators, IT Specialists.

From the Contractor's side:

1. Project Director - responsible for reporting work progress and status to the Customer.

2. Project Managers (4) - responsible for cooperating with the IT Managers, managing IT teams, reporting to the Project Director.

3. IT Managers (4) - responsible for managing IT teams.

4. IT Teams (approx. 60) - Operating System Administrators, Migration Dept, Database Administrators, Application Administrators, and Test Dept.

5. Project Office (6) - administrative support. 


\section{Project progress and encountered issues}

The migration was divided into several phases (milestones). The assumption was to migrate a specific number of servers in each phase. The planned duration of the project was nine months.

Each migration phase followed the same sequence of activities described below:

1. Pre-tests (Contractor responsible): prepare servers for migration; save initial configuration together with applications and databases installed on the servers; and perform the backup of the initial configuration.

2. Migration (Contractor responsible): migrate servers together with the operating system; applications and databases installed on the servers.

3. Post migration tests (Contractor responsible): check if servers have been migrated properly; confirm that all servers have been configured exactly the same as they were prior to the migration; check whether servers have the same parameters (CPU, disk capacity, memory size, network cards, etc.); and confirm they have all applications and databases and reflect the same image as prior to the migration.

4. Post migration tests (Customer responsible): customer checks if servers have been migrated properly.

5. The Customer has to confirm that the servers have been migrated properly.

6. Handing over of the server to the outsourcing partner for business as usual service.

One of the problems the Contractor had was that they did not have dedicated IT teams who would be involved only in this project. The team members were also working on other projects, which often resulted in delays and frustration.

There were also issues with communication between teams, probably caused by language and cultural differences. The Contractor's official language was English but the level of knowledge of this language varied among the team. But cultural differences are usually perceived by international project managers to be the biggest challenge. Every country has a different national culture and different ways of thinking about business. The most common issues the Contractor was having were related to poor quality, workers concealing problems from the management, poor international communication and corner-cutting.

An additional issue was the size of the Contractor's organisation. The company hired many thousands of people across the world. A high level of bureaucracy, procedures and formalities were slowing down the project. This directly impacted the project timelines and as a result the project budget. Another factor that caused delays was the fact that technical teams who engaged in migration processes were not only working for this project but for other projects as well. That meant that their productivity in the project was lower than it would have been had it been allocated only to the migration.

Some delays during the project were also caused by the lack of response from the Customer. The Customer's responsibility was to approve the number of servers that were about to be migrated with each migration phase. If the Customer had any doubts then they could 
have rejected the request and responded to the Contractor with feedback. Delays in receiving responses from the Customer (or a complete lack of response) caused unnecessary delays and conflicts between the Customer and the Contractor.

\section{Factors that affected the project budget}

In the opinion of the project manager, the factor that turned out to affect the budget the most was the absence of risk records. Creating and managing records would have helped in managing the risks associated with that business, and thereby associated with the project budget.

In practice, the greatest impact on the project budget was that during planning, nobody considered having the migration phases prolonged due to wrongly estimated timelines as a threat. Additionally, nobody considered allocating contingency time so that extra time slots would be available and that would allow prolonging migration. Inflexible timelines had been established for all migration phases without any safety margin in terms of time. The outcome of this was that the Company had to pay a penalty that resulted from exceeding migration deadlines.

Another unconsidered risk that had an impact on exceeding deadlines was the limitation of possible overtime hours. The limitation was dictated by the labour law particular to each country. Due to the vast numbers of overtime hours quickly accumulated by the majority of the project team, at some point some people could no longer continue working overtime. As a result, new team members had to be found to support the project, and they had to be introduced and trained before stepping into these roles, resulting in less productivity and effectiveness which then directly caused more delays in migration.

Another unpredicted risk was related to the fact that the number of human resources assigned to running the whole migration was underestimated, resulting in exceeding the salary budget of the project. This was mainly due to paid overtime - the Company had to pay higher salaries which directly affected the project budget.

The cost overrun caused by the penalty was $9 \%$ and due to higher salaries was $6 \%$. Altogether the budget was exceeded by $15 \%$.

It is thus clear that the case study, as reported by the project manager from the Contractor, confirms the statistical results showing that project risk management and using project risk management documents are crucial for keeping within the project budget. In the project in question, the budget was exceeded by $15 \%$. This together with the results of the statistical analysis shows that project management in the analysed case should be improved, among other ways, by introducing project risk management procedures and documentation.

\section{Conclusions}

In the paper significant factors for the success of IT projects in terms of budget have been identified and confirmed by a case study. The findings can be summarised as follows: 
1. In large IT companies budget overruns are usually less significant than in smaller ones.

2. In a company where many projects are run simultaneously, there are usually less significant project budget overruns than in a company which always concentrates on one single project.

3. If the customer is involved in checking the project progress only every three months, the project budget overruns are usually greater than in cases where the customer is asked to evaluate the project progress more often.

4. If systematic and documented project risk management is applied, the project budget overruns are usually smaller than in cases where it is not.

The case study confirmed the results of the research. It can be seen that large companies running several projects simultaneously, with important experience in project management, may still encounter project cost management problems, if they do not attach a sufficient importance to project risk management.

However, the case study also indicates further research directions. The project manager in the case study identified the lack of project risk management as the main factor which contributed to excessive budget overrun. However, in his testimony he identifies several concrete risk types which in their turn point to further factors whose influence on keeping the project on budget might be examined, since those factors were not included in the list of potential factors that were identified on the basis of literature. Such factors include for example: cultural and communication problems in multinational organisations; specific customer behaviour and legal problems in a multinational context.

Also specific types of organisations should be studied on their own - for example, large multinational IT companies. Further, specific projects might be considered (this research direction has already been started in the literature, which is shown in the introduction), for example, migration projects, such as in the case study. It is only then that IT project managers would really obtain concrete help in improving their project management with respect to budget.

\section{References}

Barbolla A.M.B., Corredera J.R.C. (2009), Critical factors for success in university-industry research projects, "Technology Analysis and Strategic Management" vol. 21, no. 5, pp. 599-616.

Belassi W., Tukel O.I. (1996), A new framework for determining critical success/failure factors in projects, "International Journal of Project Management" vol. 14, no. 3, pp. 141-151.

Camilieri E. (2011), Project Success: Critical Factors and Behaviours, Gower Publishing Company, Burlington.

Chan A.P.C., Chan A.P.L. (2004), Key performance indicators for measuring construction success, "Benchmarking" vol. 11 , no. 2 , pp. 203-221.

Chow T., Cao D. (2008), A survey study of critical success factors in agile software projects. "Journal of Systems and Software" vol. 81, no. 6, pp. 961-971.

Drury-Grogan M.L. (2014), Performance on agile teams: Relating iteration objectives and critical decisions to project management success factors, "Information and Software Technology" vol. 56, no. 5, pp. 506-515. 
Fan D. (2010), Analysis of critical success factors in IT project management, Proceedings of the 2010 2nd International Conference on Industrial and Information Systems, pp. 487-490.

Flyvbjerg B., Skamris Holm M.K., Buhl S.L. (2004), What causes cost overrun in transport infrastructure projects? "Transport Reviews" vol. 24, no. 1, pp. 3-18.

Fortune J., White D. (2006), Framing of project critical success factors by a systems model, "International Journal of Project Management" vol. 24, no. 1, pp. 53-65.

Jørgensen M. (2014), Failure factors of small software projects at a global outsourcing marketplace, "Journal of Systems and Software" vol. 92, no. 0, pp. 157-169.

Jørgensen M., Halkjelsvik T., Kitchenham B. (2012), How does project size affect cost estimation error? Statistical artifacts and methodological challenges, "International Journal of Project Management" vol. 30, no. 7, pp. 839-849.

Mir F.A., Pinnington A.H. (2014), Exploring the value of project management: Linking Project Management Performance and Project Success, "International Journal of Project Management" vol. 32, no. 2, pp. $202-217$.

Montequin V.R., Cousillas S., Ortega F., Villanueva J. (2014), Analysis of the Success Factors and Failure Causes in Information \& Communication Technology (ICT) Projects in Spain. "Procedia Technology" vol. 16, no. 0, pp. 992-999.

Ramos P., Mota C. (2014), Perceptions of Success and Failure Factors in Information Technology Projects: A Study from Brazilian Companies. "Procedia - Social and Behavioral Sciences" vol. 119, no. 0, pp. 349-357.

Shao J., Müller R., Turner J.R. (2012), Measuring program success, "Project Management Journal” vol. 43, no. 1, pp. $37-49$.

Standish Group (2013). Chaos Manifesto 2013, https://secure.standishgroup.com/reports (4.12.2014).

Stankovic D., Nikolic V., Djordjevic M., Cao D. (2013), A survey study of critical success factors in agile software projects in former Yugoslavia IT companies, "Journal of Systems and Software” vol. 86, no. 6, pp. 1663-1678.

Tukel O.I., Rom W.O. (2001), An empirical investigation of project evaluation criteria, "International Journal of Operations and Production Management" vol. 21, no. 3, pp. 400-416.

Wateridge J. (1998), How can IS/IT projects be measured for success? "International Journal of Project Management" vol. 16, no. 1, pp. 59-63.

Westerveld E. (2003), The Project Excellence Model $囚:$ Linking success criteria and critical success factors, "International Journal of Project Management" vol. 21, no. 6, pp. 411-418.

\title{
CZYNNIKI MAJĄCE WPLYW NA DOTRZYMANIE BUDŻETU W PROJEKTACH IT
}

\begin{abstract}
Celem artykułu jest wyznaczenie czynników, które mają istotny wpływ na dotrzymania budżetu w projektach IT. Przeprowadzono badania ankietowe, w których kierownicy projektu zostali poproszeni o określenie czy i w jakim stopniu został dotrzymany budżet prowadzonych przez nich projektów, a także o określenie różnych cech projektu, charakterystyki procesu zarządzania projektem oraz charakterystyki organizacji, w której i dla której realizowano projekt. W celu określenia czynników, które mają istotny wpływ na ryzyko przekroczenia budżetu projektu IT przeprowadzono analizę statystyczną. Przedstawiono również studium przypadku projektu IT realizowanego przez międzynarodowy zespół, w którym przeanalizowano wpływ czynników (zidentyfikowanych w analizie statystycznej) na relację pomiędzy planowanym a rzeczywistym budżetem. Istotą artykułu jest ukazanie kierownikom projektów IT, które czynniki, wyznaczone na podstawie analizy ilościowej, mają pozytywny wpływ na dotrzymanie budżetu projektu.
\end{abstract}

Słowa kluczowe: project IT; budżet projektu; sukces projektu

\section{Citation}

Gładysz B., Kuchta D., Frączkowski K., Pawlicki A. (2015), Factors which Influence Keeping within a Project Budget in IT Projects, Zeszyty Naukowe Uniwersytetu Szczecińskiego nr 855, „Finanse, Rynki Finansowe, Ubezpieczenia" nr 74, t. 1, Wydawnictwo Naukowe Uniwersytetu Szczecińskiego, Szczecin, s. 511-522; www. wneiz.pl/frfu. 